\title{
Women and Psychiatry
}

\author{
HELEN CRIMUSK and SARAH WELCH
}

\begin{abstract}
"If insanity is a disease requiring medical treatment, ladies cannot legally or properly undertake (that) treatment" J. C. Bucknill (1857), founder of the Asylum Journal, 1853 (later, British Journal of Psychiatry)
\end{abstract}

\section{Special interest group in women and poychiatry}

Last year, the Royal College of Psychiatrists approved the setting up of a special interest group on women and psychiatry. Recognition of the need to integrate research in this field occurred much earlier in the United States; the American Journal of Psychiatry has devoted two special sections to women's issues, covering both the issues of women as psychiatrists and mental illness in women. In Britain, the first International Conference on Women and Mental Health was held at the Institute of Psychiatry in 1990, and has been held yearly since, covering such issues as the law, community care and most recently the family. Interest in the field has also been stimulated by recent initiatives such as the Department of Health Conference on Women's Health as part of the 'Health of the Nation' campaign, and the United Nations World Conference on Women earlier this year in Beijing, which emphasised the objective of improving women's access at all stages of their lifestyle to good quality health care. In this article we have aimed to outline some of the issues in four main areas: mental illness in women, the impact of mental illness within the family, mental health policy and service provision, and women as psychiatrists.

\section{Mental illness in women}

Women are relatively protected from some of the more severe, preadolescent psychiatric disorders of neurodevelopmental origin. Despite this, women represent the majority of patients in most mental health treatment settings. Women are also much more likely to be prescribed psychotropic medication than men (Ashton, 1991). Community studies find an increased incidence of most psychiatric disorders among women, especially minor psychiatric morbidity, although a study which controlled for environment and sex roles and stereotypes, failed to confirm this generally accepted finding (Jenkins, 1985). There are major gender differences in the prevalence of some psychiatric disorders, such as eating disorders, which predominantly affect women, while sex ratios in other formerly male dominated disorders, e.g. alcohol disorders, may be changing.

Paykel (1991) has shown that depression in treated samples shows a 2:1 female predominance, which is not related to help seeking behaviour, and most of the excess occurs in married women aged 25 to 45 years old with children, suggesting a social causation. Being female also appears to be a risk factor for chronicity of depression (Scott, 1988). There has been considerable controversy with regards to whether the menopause is a time when women suffer an increased rate of psychiatric morbidity, as well as the cause of any such increase found. A recent review (Pearce et al, 1995) concluded that there was evidence of a small increase in psychological symptoms (not usually amounting to psychiatric disorder) preceding the menopause and following surgical menopause, and that while hormone replacement therapy is useful when there are sexual symptoms such as vaginal dryness, there is little evidence for its benefit in psychological symptoms.

In schizophrenia, community first onset studies have found a reduced incidence of schizophrenia in women (Iacono \& Beiser, 1992), and favourable differences have also been demonstrated in psychopathology (Galdos \& van Os, 1995) and in treatment response and course (Szymanski et al, 1995) in women. Castle et al (1995) have suggested that this represents differing genetic susceptibility of males and females to various subtypes of schizophrenia. The puerperium has proved a fascinating period to study; non-psychotic affective disorders have been shown to have a strong association with the social factors known to be implicated in 
depression in general (Kumar \& Robson 1984), while investigations into postpartum psychosis have failed to find such an association (Brockington et al, 1990), and dopaminergic supersensitivity has been proposed (Kumar et al, 1993). Thus differences may be based on biological differences, social influences, biases in diagnosis and treatment, or a combination of these factors.

Studies of gender differences are important in helping our understanding of psychiatric disorders, but require careful design to avoid sampling biases (Walker \& Lewine, 1993).

\section{Mental illness and the family}

There has always been a large burden on the families of the mentally ill, however, this has been of increasing magnitude in recent years since the advent of fewer and shorter hospital admissions, and the difficulty in obtaining respite care. The majority of this burden falls upon women. Kuipers (1993) has described the impact on families caring for people with schizophrenia, and emphasised the needs they have for information, help with problem solving and emotional support, as well as contunuity of care from professionals. Morris et al (1991), looking at the carers of dementia sufferers, have pointed out that there is a subjective and objective difference in strain and burden in female carers, which they attribute to differing role expectations and coping strategies. Women with mental illness are often themselves the carers of children, and Murray (1992) has shown that the mother-child relationship may be adversely affected by maternal mental illness.

\section{Service provision}

There is now increased recognition of the need for gender to be taken into account when planning services. Women with mental illness appear to be treated in different settings to men. Brown et al (1988) found that women in all diagnostic groups were preferentially referred to primary care mental health clinics rather than hospital based services, this may be the result of referral bias on the part of general practitioners, or patient choice. Perkins \& Rowland (1991) have highlighted the paucity of research concerning service usage and needs of female long-term psychiatric patients, and in their own work, have found services unresponsive, especially to older women.

While men predominate, $10-25 \%$ of the homeless are estimated to be women and half are accompanied by children (Scott, 1993). Recent studies suggest that as many as $50 \%$ of the total homeless population have some form of mental illness, but as a group they find it hard to access help (Scott, 1993). Women are a minority of the prison population, but represent a higher proportion of those with mental illness. Maden et al (1994) found an approximately twofold increase in mental handicap, personality disorder, neurosis and substance abuse among women serving a sentence compared to men, and pointed out the lack of a therapeutic community setting of the Grendon type in women's prisons.

The issue of single sex provision in hospitals and hostels is very topical at present, having been emphasised in the expanded Patient's Charter in January 1995. Patel et al (1994) found psychiatric patients were dissatisfied with mixed sex wards, and d'Orban (1993) has pointed out how difficult women may find sharing mixed hostels. Milne et al (1995), studying admissions to a regional secure unit, found a higher prevalence of personality disorder and drug and alcohol abuse among women, who were in a minority of $1: 7$, as well as an increased likelihood of transfer of women into special hospitals which was not true for men. There has been concern about the therapeutic potential for women, many of whom have been abused by men, in male dominated environments such as regional secure units, and many are arguing for single sex provision at this level.

Subotsky (1991) has described the principles upon which she feels future planning should be based. This should involve considering the mental health needs of women throughout their lifecycle and she highlights opportunities to provide help for girls and women at specific high risk times. This approach is relevant for other patient groups and could encourage a more flexible service for all users.

\section{Women as psychiatrists}

Work on gender differences among psychiatrists has received little attention here in comparison to the United States. Research has documented changing demographic trends in psychiatry manpower, with more women entering psychiatry as a career (Kastrup \& Petersson, 1986), however, it is clear that in many countries, women are still underrepresented in senior positions, particularly in academic psychiatry (Kastrup \& Petersson, 1986; Leibenluft et al, 1993). Further studies of differences in practice suggest that female psychiatrists see a higher proportion of women patients, see all their patients more frequently than male psychiatrists (Fenton et al, 1987), and that despite 
controlling for age, training, hours worked or numbers of patients seen, they have a significantly lower mean net income (Dial et al, 1994). One rather disturbing study of gender differences among American medical students showed that female medical students improved their ability to rate psychopathology during their psychiatric training, whereas male medical students actually got worse! (Fabrega et al, 1994).

The American Psychiatric Association has recognised that research findings on women in academic psychiatry have major implications, stating that:

"Women now comprise nearly one half the talent pool of potential academic psychiatrists and researchers ... Under-utilisation of talent has major implications for our ability to recruit and retain. In addition, the data indicate that the gender gap ... is greatest in research activity . . . and administrative roles. Thus, it is not so much a 'women's issue' as it is a reality that can affect the future of psychiatric research." (American Psychiatric Association, 1993)

Little comparative work has yet been done in the UK. The census data collected by the Royal College of Psychiatrists, however, gives cause for concern (Royal College of Psychiatrists, 1995). Table 1 shows the manpower data obtained from the census in 1994. The small proportion of women consultants could be explained by a cohort effect; however, the lack of a gradient among training grades does not lend support to this. The 1993 figures for academic posts in psychiatry (Table 2) are even less encouraging (Personal communication, NHS Executive 1995).

Concern has been expressed over the progress of women in fulfilling their potential within medicine, an issue which has been taken on by the Women's NHS Executive by endorsing the government Opportunity 2000 initiative, aimed at increasing the proportion of women in positions of seniority. One clear need for women is the opportunity to take career breaks and continue training part time if they wish. The part time training scheme, which aimed to allow women to reach their potential whilst working part time, is currently under review.

Table 1

Women in clinical psychiatry in England and Wales (1994)

\begin{tabular}{|c|c|c|c|c|}
\hline & $\begin{array}{l}\text { Senior House } \\
\text { Officer }\end{array}$ & Rogistrer & $\begin{array}{l}\text { Senior } \\
\text { Registrer }\end{array}$ & Consutant \\
\hline $\begin{array}{l}\text { Number of } \\
\text { women (\%) }\end{array}$ & 358 (41.1\%) & 341 (41.0\%) & 322 (44.4\%) & $675(28.5 \%)$ \\
\hline Total & 869 & 832 & 725 & 2365 \\
\hline
\end{tabular}

Table 2

Women in academic psychistry in England and Wales (1993)

\begin{tabular}{lccc}
\hline & Lecturer & Senior Lecturer & Professor \\
\hline Number of women (\%) & $66(28.3 \%)$ & $51(27.4 \%)$ & $4(6.7 \%)$ \\
Total & 233 & 186 & 60 \\
\hline
\end{tabular}

Having demonstrated that given the opportunity, women wishing to work part time can achieve their career aims, it is now anticipated that hospitals and Trusts will be expected to continue the initiative. Unfortunately, there seems little likelihood of them supplementing research training, and this is likely to act as a further barrier to women wishing to work part time in academic psychiatry.

\section{Conclusions}

The setting up of a section on women and psychiatry is likely to prove controversial. It risks being seen as a forum for sidelining 'difficult' or 'minority' issues which are of interest only to women, thus avoiding the necessity of 'mainstream' professionals to consider these issues. Others may take the opportunity of attempting to exclude men from involvement in such areas. However, the issues which the group could address are not peripheral to the field of mental health, and there is a need to ensure that the group develops as an outward-looking forum, which helps to integrate issues of particular relevance to women into the mainstream of psychiatric practice, research, education, and into mental health policy, rather than allowing them to be confined to the 'women's section'.

\section{Roforences}

American Poychiatric Association (1993) Women in academic peychiatry and rescarch. American Journal of Psychiatry, 150, 849-851.

Astron, H. (1991) Paychotropic drug prescribing for women. British Journal of Psychiatry, 158 (suppl. 10), 30-35.

Brocknnoton, I. F., MARTnN, C., Brown, G. W., et al (1990) Streses and puerperal poychosis. British Journal of Psychiatry, 157 , 331-334.

Brown, R. M., Strutribes, G., Christis Brown, J. R., el al (1988) A comparison of referrabs to primary care and hoepital outpatient clinics. British Jourmal of Psychiatry, 153, 166-173.

CASTLE, D. J., ABra, K., TAKEa, N., et al (1995) Gender differences in schizophrenia: Hormonal effect or subtypes? Schizophrenia Bulletin, 21, 1-12.

D'Orban, P. T. (1993) Female Offenders. In Forensic Psychiatry: Clinical, Legal and Ethical lssues (eds J. Gunn \& P. Taylor), pp. 599-623. Butterworth-Heinemann Ltd, Oxford. 
Dinl, T. H., Grnars, P. E., Lembenluft, E., et al (1994) Sex differences in poychiatriats' practice patterns and incomes. American Joumal of Psychiatry, 151, 96-101.

FABRECA, H., UlRich, R. \& Kastavan, M. (1994) Gender difierence in how medical students learn to rnte peychopathology. Joumal of Nervous and Mental Disease, 182, 471-475.

Fenton, W. S., Romnowrt, C. B. \& LzAp, P. J. (1987) Male and female poychiatrists and their patients. American Joumal of Psychiatry, 144, 358-361.

Galdos, P. \& VAN Os, J. (1995) Gender, peychopathology, and development: From puberty to early adulthood. Schizophrenia Research, 14, 105-112.

IACONO, W. G. \& Barsis, M. (1992) Where are the women in first onset schizophrenia? Schizophrenia Bulletth, 18, 471-480.

JENKNNs, R. (1985) Sex differences in minor peychiatric morbidity: A survey of a homogeneous population. Social Science and Medicine, 20, 887-899.

KAstruP, M. \& Petrasson, B. (1986) Working conditions of male and female poychiatriats. Acta Psychiatrica Scandinavica, 74, 84-90.

KUIPERs, L. (1993) Family burden in schizophrenia: Implications for services. Social Psychiatry and Psychiatric Epidemiology, 28 , 207-210.

Kumar, R. \& Roseon, K. M. (1984) A prospective study of emotional disorders in childbearing women. British Joumal of Psychiatry, 144, 35-47.

, MArrs, M., Wricx, A., et al (1993) Neuroendocrine and peychosocial mechaniems in poet-partum poychosis. Progress in Neuro-Psychopharmacolosy and Biological Psychiatry, 17, 571-579.

LeIBenluft, E., Dul, T. H., HAvmand, M. G., et al (1993) Sex differences in rank attainment and research activities amon academic poychiatrists. Archtves of General Psychiatry, 50, 896-904.

MAden, T., Swinton, M. \& GunN, J. (1994) Psychiatric disorder in women serving a prison sentence. British Journal of Psychiatry, 164, 44-54.
Minnz, S., Barró, P., Frasbre, K., et al (1995) Sex difierences in patients admitted to a regional eccure unit. Medictre, Science and the Law, 35, 57-60.

Morres, R. G., Woops, R. T., DAviss, K. S., et al (1991) Gender differences in carers of dementin enfierers. British Jowrnal of Psychiatry, 158 (suppl. 10), 69-74.

MURRAY, L. (1992) The impact of poet-natal depreasion on infant dovelopment. Joumal of Child Psycholosy and Psychiatry, 33, 543-561.

PAYrer, E. S. (1991) Depreasion in women. British Journal of Psychiatry, 158 (auppl. 10), 22-20.

PATE, A., Dostu, M. \& OYEoDB, F. (1994) Mixed sex wards. Psychiatric Bulletto, 18, 577.

Pearce, J., Hawton, K. \& Blare, F. (1995) Paychological and sexual symptoms aseociated with the menopanse and the effects of hormone replacement therapy. British Jowmal of Psychiatry, 167, $163-174$.

Pesurns, R. E. \& Rownav, L. A. (1991) Sex differences in service usage in long term peychiatric cares Are women adequately cerved? British Jowrnal of Psychiatry, 158 (suppl. 10), 75-79.

RoYal College of Poychitrusts (1994 \& 1995) Anumal Cenurus of Psychiatric Staffing. London: Royal College of Puychiatrists.

Scort, J. (1988) Chronic depreation. British Jowmal of Psychiatry, 153, 287-297.

(1993) Homeleaness and mental illness. British Joumal of Psychiatry, 162, 314-324.

Subotury, F. (1991) Ineves for women in the development of mental health services. British Joumal of Psychiatry, 158 (auppl. 10), 17-21.

SzMmansed, S., Lmegreman, J. A., Alvm, J. M., et al (1995) Gender differences in onset of illness, treatment response, course, and biologic indexes in first-episode schizophrenic patients. American Joumal of Psychiatry, 152, 698-703.

WALKER, E. F. \& LEWDE, R. R. J. (1993) Sampling biases in studies of gender and schizophrenia. Schizophrenia Bulletion, 19, $1-7$.

Helen Crimlisk, MRCPsych, Institute of Neurology, Queen Square, London; Sarah Welch, MRCPrych, Addictions Research Unit, Institute of Psychiatry, London SE5 8AZ

Correapondence: Dr H. Crimlisk, Department of Neuropsychiatry, Institute of Neurology, Queen Square, London WCIN 3BG

(First received 25 October 1995, final revision 5 January 1996, accepted 10 Jamuary 1996) 